\title{
Obituaries
}

\section{Sir John Peel}

Surgeon-gynaecologist to the Queen who talked the Royal College of Obstetricians and Gynaecologists into supporting the legalisation of abortion

Sir John Peel steered the Royal College of Obstetricians and Gynaecologists through the intense debates that led to it supporting abortion law reform in 1967. He also wrote the report that engineered the move of childbirth from home and into hospital. Peel attended six royal births, all of which took place at home, and he made childbirth safe for women with diabetes and their babies.

It was during his tenure as president of the royal college that Peel chaired the committee advising the government on its bill to legalise abortion, which became the 1967 Abortion Act. The college was closely involved with the government at all stages of the bill.

The abortion debate was marked by deep divisions along religious, moral, and ethical lines, and the college was no exception to this. Its council included a prominent antiabortionist, Professor Hugh Maclaren, and several Roman Catholics, who objected on religious grounds.

Peel steered the committee through this with great diplomacy and, according to his colleague John Brudenell, he talked the council round so that it came out in support of the bill. His aim was singular and focused: he wanted to reduce the amount of disease and death associated with illegal abortion.

Peel was the author of a 1971 report on domiciliary midwifery bed needs for the Department of Health and Social Security that recommended that all women should give birth in a hospital and remain there for some days. Peel's aim was to reduce maternal and infant mortality. Although this met with some resistance (many experts felt that the additional stress placed upon bed requirements was not balanced by the benefits of such care), the report caused a $\mathrm{U}$ turn in maternity practices, at the expense of domiciliary midwifery services.

The report was, however, criticised by the epidemiologist Archie Cochrane, who pointed out that there was little correlation between high hospitalisation rates and lower perinatal mortality. He asked what benefit was to be gained by keeping mothers in hospital for more than 48 hours. Cochrane said that Peel's data was thin evidence on which

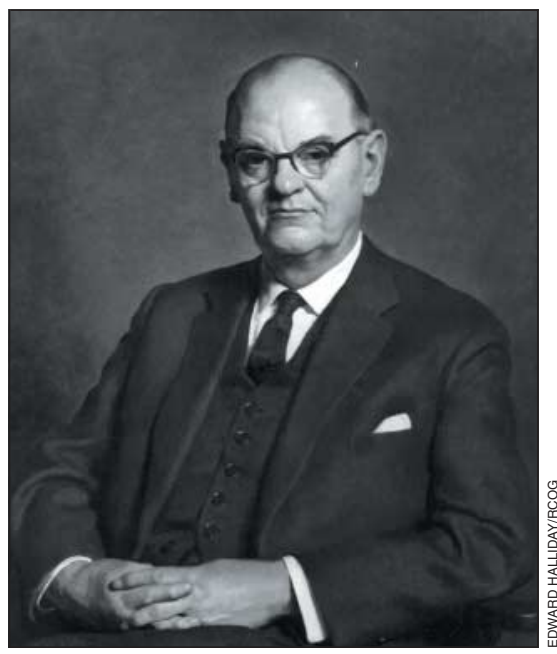

financed the college's expansion into its handsome premises in Regent's Park. He became president of the college in 1966 . From 1972 to 1976 he was chairman of the BMA board of science and education and in 1970 he was BMA president. He was also chairman of the Family Planning Association from 1971 to 1974 . This was not an active post, but he did it to lend his name and thus his support to the organisation.

He wrote many articles and a number of books from the Textbook of Gynaecology (1943) to Lives of the Fellows of the Royal College of Obstetricians and Gynaecologists 19291969 (1976).

Peel assisted at the birth of Prince Charles in 1948 and Princess Anne in 1950, both of which were supervised by his predecessor as surgeon-gynaecologist, Sir William Gilliatt. He delivered Prince Andrew in 1960 and Prince Edward in 1964; on those occasions he was assisted by John Brudenell. All these, paradoxically, were home births. As surgeon-gynaecologist to the Queen from 1961 to 1973 he also delivered Princess Margaret's children, Viscount Linley and Lady Sarah Armstrong-Jones. A quiet, unflappable Yorkshireman, Peel handled the media interest in royal births with aplomb.

He married Muriel Pellow in 1936. In 1947, while consultant surgeon at the Princess Beatrice Hospital, he scandalised his conservative colleagues by divorcing her and marrying Freda Mellish, a ward sister. Theirs was a long and happy relationship and he was overcome by her death in 1993 In 1995 Peel married an old family friend, Sally Barton, who was also recently widowed. He leaves her and a daughter by his first marriage. [CAROLINE RICHMOND]

Sir John Harold Peel, former consultant obstetrician and gynaecologist London (b 1904; q King's College London 1930; KCVO), d 31 December 2005. block at King's.

Peel became a fellow of the Royal College of Obstetricians and Gynaecologists in 1944. In 1955 he became a council member and, in 1959, honorary treasurer. As treasurer, Peel raised the funds that
Longer versions of these obituaries are available on bmj.com 


\section{Alan Margeston Harris}

Former consultant cardiologist Chelsea and Westminster Hospitals, London (b 1931; q St George's Hospital, London, 1955; BSc, MD, $F R C P$ ), died from leak of aortic aneurysm graft on 23 June 2005.

Alan Harris had a long and distinguished career at the forefront of cardiological innovation, playing a central part from the first use of a demand pacemaker in Europe to the routine implantation of transvenous pacemakers. Patients requiring a pacemaker in the south of England had only one option in the late 1950s: to have devices built and then implanted at St George's Hospital. Alan headed this highly demanding service. He leaves a wife, Fleure, and four daughters. [Stuart D Rosen, Aubrey LEATHAM]

\section{Philip John Pegg}

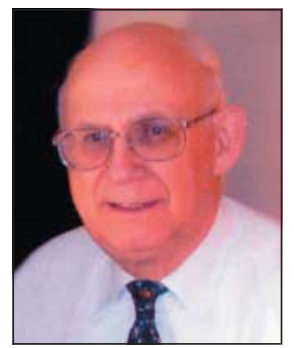

Former medical director of performance improvement Christiana Care, Wilmington, Delaware, USA (b 1936; $q$ Westminster 1960; FRCPath, AKC), died from multiorgan failure on 31 July 2005.

John was appointed medical director of clinical chemistry at the Medical Center of Delaware (now Christiana Care) in 1973, serving as chairman for eight years. He became an American citizen in 1977. In 1996 he was appointed the first medical director of performance improvement at Christiana Care and was instrumental in the organisation gaining national recognition for excellence in patient care. He leaves a wife, Kay; three children; five grandchildren; and three step grandchildren. [DAvID E PeGG]

\section{Lucien Read}

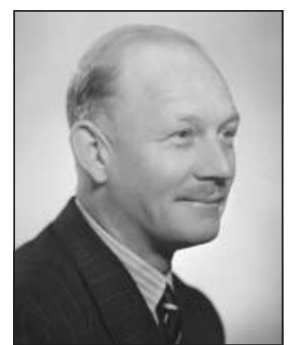

Consultant in genitourinary medicine Blackburn, Burnley, and Bury (b 1916; $q$ St Mary's Hospital, London, 1940; MA), died from a stroke on 7 December 2005.
Lucien served as a squadron leader during the second world war and from 1950 to 1981 was consultant in genitourinary medicine for Blackburn, Burnley, and Bury health authorities. At the age of 89 he was still playing bridge five times a week, golf twice, and regularly dining out. Predeceased by his wife, Bridget, he leaves two children and three grandchildren. [PAuline EdGson]

\section{Denis Wilson Robertson}

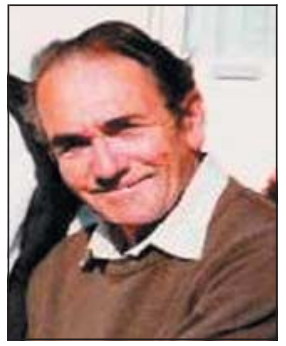

Former general practitioner Northampton (b Rhyl, north Wales, 1925; q St Mary's Hospital, London, 1950; MRCGP, Cert Aviat Med), died from cancer on 6 November 2005. After qualifying Denis joined his father in general practice, retiring in 1990. Interested in dental anaesthetics, he developed a large practice among local dental surgeons. Having learnt to fly, he held a private pilot's licence from 1960, and was appointed an authorised medical examiner for the Civil Aviation Authority in 1965. He was a clinical assistant in surgery at Northampton General Hospital for several years. Appointed a magistrate in 1968, he became chairman of the Northampton Bench in 1993. He leaves a wife, Marjorie, and two daughters. [DEREK BuLL]

\section{Cecilia Valentine Russell (née Urquhart)}

Former clinician in mother and child welfare clinics Newcastle upon Tyne (b 1920; q Aberdeen 1942; MD, DCM), d 30 October 2005.

Cecilia Valentine Russell-known as Wendy to her friends - was born in Jamaica. During the war years she worked as a house surgeon at Great Ormond Street Hospital. She married fellow student James Knox Russell in 1944 and then settled in Newcastle upon Tyne, where she worked for several years in mother and child welfare clinics. She retired from clinical practice in the early 1970s. She leaves a husband, three daughters, and four granddaughters. [HILARY LANCASTER]

\section{Mathew Philip Thoppil}

General practitioner Denton Turret surgery, Newcastle upon Tyne (b Alwaye, India, 1973; $q$ Newcastle upon Tyne 1997; FRACGP), d 20 May 2005.

Mat completed his house officer year in Sunderland and Bishop Auckland before joining the Northumbria Vocational Training Scheme, which he completed in 2002.

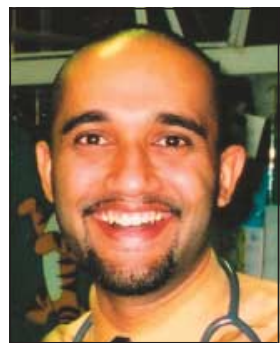

He then moved to Australia, working as a GP in Mount Gambier and Fremantle. Mat returned to the United Kingdom in 2004 and was about to become a partner. He died doing what he loved-playing squash. He leaves a wife, Julie. [JosePH THOPPIL]

\section{William Kenneth Johnstone Walls}

Former senior lecturer in anatomy Leeds (b 1917; q Leeds 1940), died from pneumonia on 8 August 2005.

Kenneth Walls's early career, punctuated by five years' war service in the Royal Army Medical Corps, was that of an aspiring surgeon. Illness, however, precipitated a change of tack. He was appointed lecturer in anatomy at Leeds in 1949, becoming arguably the best loved teacher in the medical school as "Daddy" Walls. He was made a life fellow of the university in 1982. Predeceased by a son, he leaves a wife, Marguerite; a stepdaughter; and a daughter. [L M ADAMs]

\section{Mary Lorraine Whiteside (née Stringer)}

General practitioner Newtownabbey, County Antrim, Northern Ireland (b Belfast 1955; $q$ Queen's University, Belfast, 1979; DCH, $M R C O G, M R C G P)$, died from metastatic breast cancer on 9 October 2005.

Lorraine joined Notting Hill Medical Practice over 20 years ago and soon became a valued partner. She had many attributes and skills in obstetrics, diabetic treatment, and forensic medical work, and was a great asset to the practice. She leaves a husband, Trevor, and two daughters. [Trevor Whiteside]

\section{Advice}

We will be pleased to receive obituary notices of around 250 words. Pressure on space means that in most cases we will be able to publish only about 100 words in the printed journal, but we can run a fuller version on our website. We will take responsibility for shortening. We do not send proofs. Good quality, original photographs are welcome. Please give a contact telephone number and, where possible, supply the obituary on a disk or byemail to obituaries@bmj.com If sending a picture electronically, please attach as a jpeg or a tiff rather than as part of a Word document. We need to know the year of birth and exact date of death of the deceased, and we prefer obituaries to state the cause of death. Please spell out abbreviations. 